\title{
COMMUNICATION STRATEGIES USED BY EFL STUDENTS IN IMPROVING SPEAKING SKILL
}

\author{
Rahmi Aulia Nurdini \\ rahmiaulianurdini@gmail.com
}

\begin{abstract}
This study aims to investigate communication strategies (CSs) used by EFL students in improving speaking English. Methods employed were questionnaire, observation, and interview. Findings show that students have improvement in speaking when they used communication strategies (CSs). The strategies used by the students include non-linguistic means, appeal for help, fillers or hesitation device, message abandonment, literal translation, and code switching. The present study suggests that EFL practitioners pay attention to communication strategies (CSs) aspect to obtain the optimum results of teaching-learning process.
\end{abstract}

Keywords: Communication Strategies, Speaking Skill, Efl Students

\section{INTRODUCTION}

The importance of English can be seen from the fact that English in Indonesia is taught from kindergarten up to university level. Even though Indonesian students have been learning the language for years, they still seem to have difficulties in using the language, especially spoken English. At the university level, particularly at Economics faculty, English course is important to equip students for the business field.

With regard to English courses at Economics faculty, a small-scale study at a private university has been conducted. It found that the majority of second semester students majoring in management felt reluctant, shy and worried when speaking English; only a few students were willing to speak English in the classroom. However, students willing to speak English still got difficulty in expressing ideas and thoughts. They need to know communication strategies (CSs) to overcome their limitations. CSs are considered as one of fundamental factors in promoting students' ability to improve their speaking skills, and CSs can help them overcome communication difficulties such as lack of vocabulary, pronunciation, grammar and other linguistic factors.

CSs are strategies that learners use to overcome problems in order to convey their intended meaning. Abulfazl and Esmaeel (2014) explains, "Communication strategies refer to all those techniques that language learners employ, in spite of a deficient language competency, when target language items are not available”. Besides, CSs are considered to play an important role in language acquisition (Huang, 2010). Dornyei (1995) divides CSs into some categories, among others, avoidance/reduction strategies, achievement/compensatory strategies, and stalling/time-gaining strategies. In reduction strategy, speakers leave unfinished message as they do not know how to say a word. While in 
compensatory strategy, speakers paraphrase or describe a topic or thing. Moreover, in timegaining strategy, they use fillers and pauses.

All EFL students encounter problems in communication. Linguistic problem is one of the problems such as difficulties in pronunciation, vocabulary, or grammatical; while nonlinguistic problems relate to learners' personality. Previous researches have investigated studies pertinent to communication strategies. Nakatani (2010) conducted a study at a Japanese college to investigate if the application of specific communication strategies help increase EFL students' proficiency in communicative tasks. It found that 'maintaining discourse' and 'meaning negotiation' strategies helped promote students' communicative ability. In addition, Mei and Nathalang (2010) investigated non-English major undergraduate students studying English at a Chinese university. The study investigated CSs used by the students, and it found that the CSs were affected by three aspects: the type of task, their language proficiency, and academic major. These communication strategies were also investigated by Septy (2012) proving that the students used certain strategies in speaking activity to cope their anxiety.

The studies above show that knowing communication strategies has benefits for EFL students. Besides, there is a very little information on the study investigating communication strategies in Indonesian EFL setting. This study is therefore interested in exploring the topic qualitatively, and it poses the following research questions: (1) Is there any improvement on students' speaking skill when they use communication strategies? (2) What are possible strategies used for low self-esteem students in improving their speaking skill?

\section{METHODS}

This study adopted the principles of qualitative inquiry and took place at the Economics faculty in a private university Jakarta, Indonesia. Six students participated in the study. Data collection methods were observation, speaking test, and interview. In the observation stage, the researcher investigated the students' behavior, for example, what students do in the classroom during speaking class, do they look confident or shy when speaking English?, so forth. In speaking test, the researcher analyzed data from video recording to find out kinds of communication strategies. The data were matched with the data from class observation, speaking test, and interview.

\section{FINDING}

The findings showed that when they had to speak English during class activity both in the classroom and in the speaking test, they often used many non-linguistic strategies such as message abandonment, use of all-purpose words, literal translation, non-linguistic means, code switching, asking-for-help, and use of fillers or hesitation device strategies. All the 
strategies were helpful for them to increase their ability in English speaking skill. Some of them used the communication strategy consciously and others used it unconsciously.

Table 1: CSs used by EFL students during observation and speaking test

\begin{tabular}{|l|c|}
\hline Communication Strategies & CSs Used by Students \\
\hline Avoidance or reduction: & $\sqrt{ }$ \\
Message abandonment & \\
Topic avoidance & \\
\hline Achievement or compensatory: & \\
Circumlocution & $\sqrt{ }$ \\
Approximation & \\
Use of all-purpose words & $\sqrt{ }$ \\
Word coinage & $\sqrt{ }$ \\
Use of non-linguistic means & \\
Literal translation & $\sqrt{ }$ \\
Foreignizing & $\sqrt{ }$ \\
Code switching or language switch & \\
Appeal for help & $\sqrt{ }$ \\
\hline Stalling or time-gaining: & \\
Use of fillers/hesitation & \\
Device & \\
\hline
\end{tabular}

The table above shows that when they employed Communication strategies (CSs), they are more confident and motivated. Even though they found difficulty in speaking English, they could find some strategies to express their language. The findings of this study support findings of previous studies showing that communication strategies can influence students' language performance especially in speaking skill. This finding could bring further investigation which relates learning or communication strategies in English speaking skill.

\section{CONCLUSION}

This study found that students used kinds of CSs in improving their speaking English skill: message abandonment, achievement or compensatory strategies (non-linguistic means, literal translation, code switching, appeal for help), and stalling or time-gaining strategies (fillers or hesitation device). The possible strategies used for the students in improving their speaking skill are adopting CSs used by students.

Findings of this study suggest several points to the EFL practice. Firstly, communication strategies need to be considered by EFL practitioners. Students need 
attention from teachers in order that they also get the optimum results of teaching-learning processes. Finally, this study only adopted a few numbers of participants, so the results might not really reflect the EFL condition in Indonesia. Therefore, further studies need to consider more participants and different EFL setting.

\section{REFERENCES}

Bagheri, M. S., \& Faghih, M. (2012). The relationship between self-esteem, personality type and reading comprehension of Iranian EFL students. Theory and Practice in Language Studies, 2(8), 1641-1650.

Bandung: Indonesia University of Education.

Fahim, M., \& Rad, S. K. (2012). The relationship between self-esteem and paragraph writing of Iranian EFL learners. Psychology, 3(1), 24-29.

Ghaith, G. (2010). Effects of the learning together model of cooperative learning on English as a foreign language reading achievement, academic self-esteem, and feelings of school alienation. Bilingual Research Journal: The Journal of the National Association for Bilingual Education, 27(3), 451-474.

Huang, C. (2010). Exploring factors affecting the use of oral communication strategies.

Indrianty. Septy. (2012). A Thesis. Students' Anxiety in Speaking English.

Juyandegan, M. (2016). The relationship between self-esteem and reading comprehension of EFL Iranian pre-university learners. International Journal of Asian Social Science, 6(5), 303-313.

Mei, A., \& Nathalang, S. S. (2010). Use of communication strategies by Chinese EFL learners. Chinese Journal of Applied Linguistics, 33(3), 110-125.

Mesgarshahr, A and Abdollahzadeh, E. (2014). The impact of teaching communication strategies on EFL learners" willingness to communicate. SSLT 4 (1), pp. 51-76.

Nakatani, Y. (2010). Identifying strategies that facilitate EFL learners' oral communication: A classroom study using multiple data collection procedures. The Modern Language Journal, 94(1).

Retrieved June 3, 2016 from http://www.lhu.edu.tw/m/oaa/synthetic/ publish/publish/30/8.\%E9\%BB\%83\%E7\%A7\%8B\%E8\%90\%8D-

Exploring\%20Factors\%20Affecting\%20the\%20Use\%20of\%20Oral\%20Communicatio n \%20Strategies.pdf 